\title{
Training of Andragogic Learning through Model Experiential Learning for Equality Education
}

\author{
Heryanto Susilo, Rivo Nugroho \\ Department of Non-Formal Education \\ Universitas Negeri Surabaya \\ Surabaya, Indonesia \\ heryantosusilo@unesa.ac.id
}

\begin{abstract}
To improve the professional competence of Equality in learning, an andragogic learning approach is needed with the experiential learning model or often known as experiential learning cycle, which is a learning process based on experience. The journey of life that has been traversed to the stage of maturity, of course, has passed various experiences. This makes adults rich in experience and can be a source of learning. At the same time, adults who follow can also be the basis for gaining new experiences. Learning through experience has implications for the selection and use of methods and techniques of learning or training. In practice, more learning uses group discussion, brainstorming, collaboration, and field practice. But in reality, the implementation of learning in educational units, still lacks attention to the achievement of student competencies. The old paradigm is still inherent because of habits that are difficult to change, the paradigm of teaching is still maintained and has not turned into a paradigm of teaching students, namely students are always the main actors or actors in learning activities so that the results are able to provide maximum competency provision for students in everyday life.
\end{abstract}

Keywords-model of experiential learning; non-formal educators; equality education

\section{INTRODUCTION}

Equality education is one of the primary and secondary education programs on the path of non-formal education equivalent to elementary/middle/high school. Equality education is intended for anyone who is constrained to formal education or interested and chooses equality education for completeness of primary and secondary education. The Equality Education Program diploma holders have the same eligibility rights as an elementary/junior/ high school diploma [1]. The learning process in each equality education unit both A-Package, B-Package and C-Package must be carried out interactively, inspiring, fun, challenging, motivating students to actively participate, and providing sufficient space for initiative, creativity, and independence according to talent, and the physical and psychological development of students [2].

Learning is the process of interaction of students with educators and learning resources in a learning environment both formal and non-formal education environments [2]. This means that learning is an activity carried out by educators and students in a particular learning environment by utilizing relevant learning resources and referring to the applicable curriculum. But in reality, the implementation of learning in educational units, still lacks attention to the achievement of student competencies. The old paradigm is still inherent because of habits that are hard to change, the teaching paradigm is still maintained and has not turned into a paradigm of teaching students, namely students are always the main actors or actors in learning activities so that the results are able to provide maximum competency provision for students in everyday life [3]. To carry out learning that can produce competent students, the role of professional tutors (educators, teachers) must be supported.

Educators or tutors in adult learning citizens are people who are capable of acting as learning guides. Educators or tutors on the Non-Formal Education path are required to be able to carry out learning tasks and master a set of abilities or competencies. Competencies in question are pedagogic competence, andragogic competence, personality competence, social competence and professional competence. With that competences, a tutor will be able to provide learning that can produce competencies for their learning society. To carry out learning that can produce competent students, the role of professional tutors (educators, teachers) must be supported. This is in accordance with the statement of Djamarah and Zein [4] that the key to the success of education in practice is how the teachers involved are managed as the main human resources of education. How good the system is, however complete the infrastructure is and however great the curriculum remains the key factor is in the hands of the teacher, because the teacher is the man behind all that.

In adult education is known as the term experiential learning cycle, which is a learning process based on experience. Learning through experience has implications for the selection and use of methods and techniques of learning or training [5]. In practice, learning or training uses more group discussions, brainstorming, laboratory work, field practice, and so on. Experiential learning theory (ELT) learning model, which later became the basis of experiential learning models, was developed by David Kolb around the early 1980s. This model emphasizes a learning model that is holistic in the learning process. In experiential learning, experience has a central role in the learning process. The Experiential Learning model is a learning process model that activates learners to build their knowledge and skills through their experiences directly. In this case, Experiential Learning uses experience as 
a catalyst to help learners develop their capacities and abilities in the learning process. This is different from the traditional learning approach where students become passive listeners and only teachers control the learning process without involving students.

The results of the preliminary study at the Gresik District SKB (District Technical Office for Early Childhood, Nonformal and Informal Education) which held Equality CPackage Education there were educators / tutors who needed to improve their professional competence, especially in the field of implementing learning and conducting assessment of learning outcomes. These two things determine the success or failure of the learning community in learning which in the end competency is still weak. The number of equivalence tutors in C-Package, which amounts to 20 people with a bachelor's degree qualification. With these conditions, it is necessary to increase the ability to carry out good learning and the ability to carry out learning assessments. With this increase in capacity it is expected that the quality of C-package learning and learning outcomes will increase. For that matter, it is necessary to be given a learning model that views students as adults with different characteristics from students at the level below.

On that basis, it is necessary to be given training by applying experiential learning models to improve tutors' competencies in carrying out learning and conducting learning evaluations so that directly perceived is an increase in the competency of learning citizen equality C-Package so that it is expected to produce graduates who are not only complete but have independent competency or work. This study aims to improve the competence of equality C-Package tutors in Gresik Regency SKB (District Technical Office for Early Childhood, Non-formal and Informal Education) in carrying out learning with andragogy approaches, including andragogic learning in the experiential learning model, to improve tutors' competence in carrying out and conducting C-Package lessons in Gresik Regency SKB (District Technical Office for Early Childhood, Non-formal and Informal Education).

\section{METHOD}

\section{A. Research Design}

Training is one type of learning process to acquire and improve skills outside the human resource development system, which applies in a relatively short time with methods that prioritize practice rather than theory. The approach used to improve the competency of tutors in equality in C-Package is to approach tutors' competency development through training. The definition of training in Community Service held a learning process activity for C-Package tutors to obtain knowledge and skills in order to improve individual attitudes and behavior in carrying out work and daily life.

\section{B. Research Subject}

The method applied in the training is a workshop method for mutual learning among participants and facilitated by speakers. The material to be delivered in the workshop included teaching materials about andragogic learning with the experimental learning model, steps to apply or use the experiential learning model, evaluation of learning experimental models in learning C-Package at SKB (District
Technical Office for Early Childhood, Non-formal and Informal) district of Gresik.

\section{RESULTS AND DISCUSSION}

\section{A. Research and Information Collecting}

The Experiential Model Andragogy Learning Training for Package C Equality Educators in the Gresik Regency SKB (District Technical Office for Early Childhood, Non-formal and Informal) was conducted to improve the ability of Education in organizing learning and when linked to learning citizens in the Equivalent Education Package C, John Dewey stated that "learning citizens are not only prepared to be ready to work, but can also live his real life to death. Citizens learn to think and their minds can function in everyday life. Truth is an idea that must be able to function real in practical experience [6].

The Training of Andragogy Learning Model Experiential Learning for C-Package Educator in Gresik Regency SKB (District Technical Office for Early Childhood, Non-formal and Informal) Training was held for 2 days, Monday and Tuesday, October 8th-9th 2018 with the concept of Andragogy carried out to improve the ability of Education in conducting learning.

Education in a humanistic non-formal education program is a concentration of learning citizens. In this orientation, educators do not need to know the best, especially when working with adult learning citizens. Educators act as facilitators, helpers, and partners in the learning process. Educators do not provide information directly about a subject matter, but educators play a role in creating conditions for learning to take place. In order to become a facilitator, educators must trust the learning community to be responsible for learning, respecting and using the experiences and potential of the learning community. Humanistic educators describe the action of learning as a very high personal effort, a citizen learns to learn what he considers necessary, important, or meaningful.

Educators assume the role of facilitators, helpers, and partners in the learning process. Educators do not provide information directly about a subject matter, but educators play a role in creating conditions for learning. In order to become a facilitator, educators must trust learning citizens to be responsible for learning, respecting and using the experiences and potential of learning citizens. Humanistic educators describe the act of learning as a very high personal effort, a citizen learns to learn what he considers necessary, important, or meaningful. Understanding depends on personal ultimate goals, interests, attitudes, beliefs and so on. Carl Rogers combines and popularizes the practical application of humanistic educational philosophy. The emphasis of Rogers is based on self-directed learning that is relevant to learning citizens, that is, citizens learn to participate in planning and evaluation, where educators as facilitators and group methods have been used as models for adult educators.

Experiential learning models define learning as a process that is obtained through a combination of gaining experience (grasping experience) by transforming experience 
(transformation of experience) [7]. The Experiential learning model describes two models of obtaining information, namely concrete experience and abstract conceptualization, and two models of experience transformation namely reflective observation and active experimentation. Experiential learning is a learning process that is educative, student-centered, and activity-oriented. Personal reflection on an experience and formulating a plan to determine what has been gained from scientific experience for other scientific contexts is a critical factor in maintaining the effectiveness of Experiential learning. The experiences experienced by students have an important role in forming cognitive knowledge in the minds of students. Students reflect on their experience of a new knowledge. Student involvement in experimental activities will make individuals gain concrete direct experience.

\section{B. Planning}

Experience gives an important role in the construction of knowledge. Madnesen \& Sheal suggested that meaningful learning depends on how to learn. If learning only by reading meaningful learning can reach $10 \%$, from hearing $20 \%$, from seeing 30\%, hearing and seeing 50\%, communicating reaching $70 \%$, and learning by doing and communicating can reach $90 \%$. It is clear that learning activities with the active role of students in real experiences can optimize activities in achieving learning goals.

Kolb [8] suggests 3 characteristics of Experiential learning models, namely 1) learning is best accepted as a process, where concepts are obtained and modified from experimental activities, not stated in the form of products, 2) learning is a continuous process departing from experience, and 3 ) the learning process requires conflict resolution. Experiential learning models emphasize the role of experience in the learning process, the importance of active student involvement, and intelligence as an impression of interaction between students and their environment. Prior experiences in MPE are very important as a starter in the ongoing learning process. Kolb said "learning is a process, in which knowledge is created through transformation of experience".

Learning activities is a process. Knowledge is formed through the transformation of student experience-related to the above understanding, it can be seen that the characteristics of experiential learning are very suitable if applied to the citizens of adult learning so that they fulfill the six principle requirements in adult learning. The first is the learner's need to know: how learning is carried out, and what learning will emerge and why learning is very important [9]. Second. selfdirected learning is the ability to take control of the techniques and of the purposes of learning. Third. prior experience of the learner impacts learning in creating individual differences, providing rich resources. creating biases and providing adults' self-identity.

The involvement of students in experimental activities will make individuals gain direct concrete experience. According to Bruner, when students are involved in experimental experience activities, they will develop the ability to solve existing problems [10]. Students or individuals will then develop observation skills and then reflect on the experiences they have gained. After this phase, students will form generalizations in their minds which then produce an implication that becomes a handle in new experiences. Kolb outlines some of the benefits of applying learning based on experience as follows [11]:

1. Provide appropriate learning directions in the application of what is learned.

2. Provide direction of the range of learning methods needed.

3. Provides a close link between theory and practice.

4. Clearly formulate the importance of students to reflect and stimulate students to give feedback about what they are learning.

5. Assist in combining teaching styles so that learning becomes more effective.

Experiential learning is described in a learning cycle that is hierarchical in each phase. There are four stages of the experiential learning model, namely Concrete Experience, Reflective Observation, Abstract Conceptualization, Active Experimentation. Sharlanova [12] conveys learning activities in the Kolb learning cycle as follows.

1. Concrete Experience (CE). In the concrete experience stage, students either individually, in a team, or in an organization only do the work. The intended task is a scientific activity that encourages them to carry out scientific activities or experience a phenomenon that will be studied. Students act as active participants. This phenomenon can depart from experience that has been experienced before both formal and informal, or situations that are real problematic so as to arouse student interest to investigate further.

2. Reflective Observation (RO). In the refective observation stage, students review what has been done or learned. Listening skills, giving attention or responses, finding differences, and applying ideas or ideas can help in obtaining the results of reflection. Students pay close attention to the scientific activities that are being carried out using the five senses (feelings) or feelings (feelings) then reflect on the results obtained. At this stage students communicate with each other the results of the reflection that is done.

3. Abstract Conceptualization (AC). The abstract conceptualization stage is a mind-on stage or "think" phase in which students are able to provide a mathematical explanation of a phenomenon by thinking about, observing the reasons for reciprocal-causing relationships to experiences gained after observing and reflecting on experience. science in the concrete experience phase. Students try to conceptualize a theory or model of observed experience and integrate new experiences gained with prior experience.

4. Active Experimentation (AE). At this stage, students try to plan how to test the ability of a theory or model to explain new experiences gained next. The meaningful learning process will occur at the active experimentation stage [13]. The experience gained by previous students can be applied to new experiences and / or new problematic situations. Through this active experimentation activity students will 
practice critical thinking skills. Students know the extent of understanding that has been had in solving problems related to everyday experiences. There are important stages in teaching using the Experiential learning model summarized in the learning syntax. According to Mardana [13], the Experiential learning model is able to provide stages of learning that emphasize the transformation process of the scientific experience departing from everyday experience

Experiential learning theory is a holistic and multilinear model specifically for adult development, which is consistent with what is known about how people learn, grow and develop. This theory emphasizes more on experiences that have an important role in the learning process so that it differentiates with other models.

Experiential learning is defined as "the process where knowledge is created through the transformation of experience. Knowledge results from the combination of grasping and transforming experience" [8]. Experiential learning emphasizes human capacity to reconstruct experiences and then interpret them. Dewey believes that in education is an ongoing process to reconstruct and grow experiences, where the role of educators is to manage learning activities that are built from past experiences of learning citizens and connect them to new experiences [14].

Experiential learning theory provides avenues and alternatives in learning, providing a concrete understanding of how a class can learn better (Sharlanova, 2004). Witherington revealed the characteristics of educational experiences are centered on a meaningful purpose for children, continuous with the child's life, interaction with the environment, and increase integration of children "... the process is learning is doing, reacting, undergoing, and experiencing. The product is all achieved by the learner through his own activity ... " [4].

Experiential learning is such that adult teaching should be based on adults' experiences. Thus, those experiences could be a valuable resource. Finally, learning to learn is very crucial for adult development. When they become skilled at learning, adults have the ability of lifelong learning [15]. Experiential learning is adult learning that must be based on the experience of learning citizens, where experience becomes a very valuable source, when adults are skilled in learning, then they have the ability to learn throughout their lives.

The fourth principle is readiness to learn. Adults have readiness to learn when their life situations encourage them to learn. The fifth principle is orientation to learning. In general, adults prefer orientation to problem solving in learning, where they can learn in the context of life today. the sixth principle is motivation to learn. Adults have high motivation when they can get new knowledge for them in solving life problems.

\section{CONCLUSION}

The training for equality C-Package tutors in Gresik District SKB (District Technical Office for Early Childhood, Non-formal and Informal) using the Andragogy Learning Experiential Learning Model went smoothly and well. It can be concluded that this training can be 1). Improving the ability of education in conducting learning based on real/direct experience. 2). Able to bring educators easier in conducting learning evaluations 3). Improve competence in professional and pedagogic in carrying out learning.

\section{REFERENCES}

[1] Z. Nuzula, "Pengelolaan Program Pendidikan Kesetaraan Di Pusat Kegiatan Belajar Masyarakat (PKBM) Mandiri Kecamatan Kretek Kabupaten Bantul," Hanata Widya, vol. 5, no. 2, 2016.

[2] N. R. Asih, W. Wilson, and W. Widiastuti, "Implementasi Pembelajaran Paket C di Pkbm Bina Karya pada Kelompok Belajar Desa Tibawan Kecamatan Rokan IV Koto Kabupaten Rokan Hulu," J. Online Mhs. Fak. Kegur. dan Ilmu Pendidik. Univ. Riau, vol. 3, no. 2, pp. 1-9.

[3] M. Boekaerts, "Self-regulated learning: A new concept embraced by researchers, policy makers, educators, teachers, and students," Learn. Instr., vol. 7, no. 2, pp. 161-186, 1997.

[4] S. B. Djamarah and A. Zain, "Jakarta: Rineka Cipta," 2002.

[5] E. Siegel, J. G. Jennings, J. Conklin, and S. A. Napoletano Flynn, "Distance learning in social work education: Results and implications of a national survey," J. Soc. Work Educ., vol. 34, no. 1, pp. 71-80, 1998.

[6] U. Syohih, "Lingkungan dan pendidikan Indonesia." Diakses pada tanggal, 2008.

[7] J. Kalengkongan, "Peningkatan Hasil Belajar Sains Melalui Model Pembelajaran Berbasis Pengalaman (Eksperiential Learning)," in Jurnal Forum Pendidikan, 2019, vol. 14, no. 2.

[8] D. A. Kolb, "Experience as the source of learning and development," Up. Sadle River Prentice Hall, 1984.

[9] M. S. Knowles, E. F. Holton, and R. A. Swanson, "The adult learner Houston," Tex Gulf, pp. 12-13, 1998.

[10] N. Ozek and S. Gönen, "Use of J. Bruner's learning theory in a physical experimental activity," J. Phys. Teach. Educ. Online, vol. 2, no. 3, pp. 19-21, 2005.

[11] A. B. Adam, D. C. Kayes, and D. A. Kolb, "Experiential Learning In Teams," Artik. Tersedia di http//www. Learn. com/research_Libr. pada tanggal, vol. 11, 2004.

[12] V. Sharlanova, "Experiential learning," Trakia J. Sci., vol. 2, no. 4, pp 36-39, 2004.

[13] I. B. Mardana, "Implementasi Modul Eksperimen Sains Berbabis Kompetensi dengan Model Experiential Learning dalam Upaya Meningkatkan Kualitas Pelaksanaan KBK dalam Pembelajaran Sains," J. Pendidik. dan Pengajaran IKIP Negeri Singaraja, vol. 39, no. 4, pp. 676-943, 2006.

[14] D. A. Kolb, Experiential learning: Experience as the source of learning and development. FT press, 2014.

[15] T. C. Clapper, "Beyond Knowles: What those conducting simulation need to know about adult learning theory," Clin. Simul. Nurs., vol. 6 , no. 1, pp. e7-e14, 2010. 